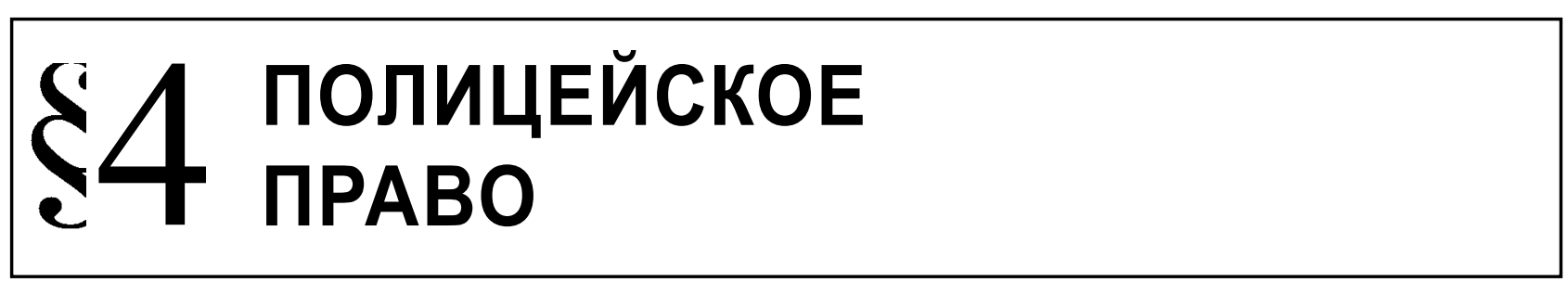

Митрохин В.В.

\title{
АДМИНИСТРАТИВНЫЕ ПРОЦЕДУРЫ ПРОХОЖДЕНИЯ СЛУЖБЫ В ОРГАНАХ ВНУТРЕННИХ ДЕЛ
}

\begin{abstract}
Аннотация: Одним из важнейших мероприятий в процессе становления правового государства и гражданского общества является подготовка кадров для всех органов государственной власти. Но в первую очередь это касается подготовки кадров и реализации кадровой политики в органах, призванных эту власть поддерживать и защищать. Настоящее исследование посвящено анализу административно-правовых средств обеспечения кадровой политики в органах внутренних дел, как составной части государственной кадровой политики. Данный подход позволяет увидеть общие закономерности в реализации государственной кадровой политики и через их призму высказать предложения по совершенствованию административно-правовых средств реализации административных процедур прохождения службы в органах внутренних дел. В процессе подготовки статьи применялись общефилософский, теоретический, эмпирический методы (диалектика, системный метод, анализ, синтез, аналогия, дедукция, наблюдение, моделирование), традиционно-правовые методы (формально-логический), методы, используемые в конкретно-социологических исследованиях (статистические, экспертные оценки и др.). Министерство внутренних дел Российской Федерации, определяя концептуальные основы ведомственной кадровой политики, исходит из необходимости формирования нового профессионально-нравственного облика сотрудника органов внутренних дел Российской Федерации, обновления кадрового потенциала полицейских и иных подразделений Министерства. Кадровая политика Министерства внутренних дел Российской Федерации - комплекс идей, принципов и норм, регулирующих деятельность руководителей органов, организаций и подразделений МВД России по формированию кадрового состава, управлению сотрудниками, федеральными государственными гражданскими служащими, работниками органов внутренних дел.

Ключевые слова: кадры, МВД, полиция, служба, правоохрана, процедура, контракт, конкурс, регулирование, увольнение.
\end{abstract}

$\mathbf{M}$ инистерство внутренних дел Российской Федерации, определяя концептуальные основы ведомственной кадровой политики, исходит из необходимости формирования нового профессионально-нравственного облика сотрудника органов внутренних дел Российской Федерации, обновления кадрового потенциала полицейских и иных подразделений Министерства. Кадровая политика Министерства внутренних дел Российской Федерации - комплекс идей, принципов и норм, регулирующих деятельность руководителей органов, организаций и подразделений МВД России по формированию кадрового состава, управлению сотрудниками, федеральными государственными гражданскими служащими, работниками органов внутренних дел.

Кадровая политика МВД России является неотъемлемой составной частью государственной кадровой политики, реализуемой в федеральном органе исполнительной власти в сфере внутренних дел через работу с личным составом.

Необходимо отметить, что служба в органах внутренних дел является федеральной государственной службой, которая представляет собой профессиональную служебную деятельность граждан Российской Федерации на должностях в органах внутренних дел Российской Федерации, а также на должностях, которые не относятся к должностям органов внутренних дел. Служба в органах внутренних дел имеет определенную специфику по сравнению с государственной гражданской и военной службой. Особенности службы в органах внутренних дел обусловлены теми задачами и функциями, которые стоят перед Министерством внутренних дел Российской Федерации. Прохождение службы в органах вну- 
тренних дел включает различные этапы, которые в целом ряде случаев влекут за собой изменение служебно-правового статуса сотрудника. Различные аспекты служебных отношений в сфере внутренних дел регламентируются достаточно большим количеством нормативных правовых актов, в частности к таковым относятся Федеральный закон от 7 февраля 2011 г. «0 полиции» ${ }^{1}$, Федеральный закон от 30 ноября 2011 г. «0 службе в органах внутренних дел Российской Федерации» ${ }^{2}$, Указ Президента РФ от 22 ноября 2012 г. «Вопросы прохождения службы сотрудниками органов внутренних дел Российской Федерации» ${ }^{3}$, Постановлением Правительства РФ от 6 декабря 2012 г. «Об утверждении Правил профессионального психологического отбора на службу в органы внутренних дел Российской Федерации»", Приказ МВД России от 30 ноября 2012 г. № 1065 «0 некоторых вопросах назначения на должности в органах внутренних дел Российской Федерации и увольнения со службы сотрудников органов внутренних дел Российской Федерации» ${ }^{5}$, Приказ МВД России от 14 марта 2012 г. № 170 «0 порядке проведения аттестации сотрудников органов внутренних дел Российской Федерации» ${ }^{6}$, Приказ МВД России от 19 января 2012 г. № 34 «0 примерной форме контракта о прохождении службы в органах внутренних дел Российской Федерации» ${ }^{7}$, Приказ МВД России от 18 апреля 2012 г. № 522 «Об утверждении Порядка оформления личного поручительства при поступлении на службу в органы внутренних дел Российской Федерации и Категорий должностей, при назначении на которые оформляется личное поручительство» ${ }^{8}$, Приказ МВД России от 30 августа 2012 г. № 827 «Об утверждении Порядка формирования кадровых резервов Министерства внутренних дел Российской Федерации, его территориальных органов и подразделений» ${ }^{9}$ и др.

\footnotetext{
Собрание законодательства РФ. 2011. № 7. Ст. 900.

Собрание законодательства РФ. 2011. № 49 (ч. 1). Ст. 7020.

Собрание законодательства РФ. 2012. № 48. Ст. 6668.

Собрание законодательства РФ. 2012. № 50 (ч. 6). Ст. 7075.

5 Российская газета. 2013. 25 января.

6 Российская газета. 2012. 27 апреля.

Российская газета. 2012. 10 февраля.

8 Российская газета. 2012. 11 июля.

9 Российская газета. 2012. 10 декабря.
}

Прием на службу в органы внутренних дел. На службу в органы внутренних дел вправе поступать граждане не моложе 18 лет независимо от пола, расы, национальности, происхождения, имущественного и должностного положения, места жительства, отношения к религии, убеждений, принадлежности к общественным объединениям, владеющие государственным языком Российской Федерации. Помимо этого, граждане, претендующем на поступление на службу в органы внутренних дел должны соответствовать квалификационным требованиям, которые установлены законом, а также быть способными по своим личным и деловым качествам, физической подготовке и состоянию здоровья выполнять служебные обязанности сотрудника органов внутренних дел. Зачисление в образовательное учреждение высшего образования МВД России для обучения по очной форме в должности курсанта (слушателя) является поступлением на службу в органы внутренних дел. В образовательные организации высшего образования федерального органа исполнительной власти в сфере внутренних дел для обучения по очной форме вправе поступать, в том числе и граждане не достигшие возраста 18 лет $^{10}$.

Нужно отметить, что предельный возраст поступления на службу в органы внутренних дел различный. Так, для замещения должностей начальствующего состава в органах внутренних дел он составляет 35 лет, а для поступления в образовательные организации высшего образования МВД России для обучения по очной форме - 25 лет.

Гражданин Российской Федерации не может быть принят на службу в органы внутренних дел в случаях, если он: имеет вид на жительство или иной документ, подтверждающий право на постоянное проживание гражданина Российской Федерации на территории иностранного государства; является подозреваемым или обвиняемым по уголовному делу; неоднократно в течение года, предшествовавшего дню поступления на службу в полицию, подвергался в судебном порядке административному наказанию за совершенные умышленно административные правонарушения; а также не согласен соблюдать ограничения, запреты, выполнять обязанности и нести ответственность, установленные для сотрудников органов внутренних дел. Гражданин не может быть принят на службу в органы внутренних дел, а также на-

10 См.: Костенников М.В., Куракин А.В. Акутальные проблемы административного права. - М., 2013. - С. 56. 
ходиться на службе в случаях: признания его недееспособным или ограниченно дееспособным по решению суда, которое вступило в законную силу; осуждения его за преступление по приговору суда, которое вступило в законную силу, а равно при наличии судимости, в том числе снятой или погашенной; прекращения в отношении его уголовного преследования за истечением срока давности, в связи с примирением сторон, вследствие акта об амнистии, в связи с деятельным раскаянием; отказа от прохождения процедуры оформления допуска к сведениям, составляющим государственную и иную охраняемую законом тайну, если выполнение служебных обязанностей по замещаемой должности в полиции связано с использованием таких сведений; несоответствия требованиям к состоянию здоровья сотрудников органов внутренних дел; близкого родства или свойства (родители, супруги, дети, братья, сестры, а также братья, сестры, родители, дети супругов и супруги детей) с сотрудником полиции, если замещение должности связано с непосредственной подчиненностью или подконтрольностью одного из них другому; выхода из гражданства Российской Федерации; приобретение или наличие гражданства (подданства) иностранного государства; представления подложных документов или заведомо ложных сведений при поступлении на службу в полицию.

Граждане, поступающие на службу в органы внутренних дел, проходят в порядке, определяемом МВД России, психофизиологические исследования (обследования), тестирование, направленные на выявление потребления без назначения врача наркотических средств или психотропных веществ и злоупотребления алкоголем или токсическими веществами. Кроме того, на гражданина, поступающего на службу в органы внутренних дел, оформляется личное поручительство, которое состоит в письменном заявлении сотрудника органов внутренних дел, имеющего стаж службы не менее трех лет, о том, что он ручается за соблюдение указанным гражданином ограничений и запретов, установленных для сотрудников законодательством.

Испытание при поступлении на службу в органы внутренних дел. Для гражданина, поступающего на службу в органы внутренних дел, в целях проверки уровня его подготовки и соответствия должности в органах внутренних дел, на замещение которой он претендует, устанавливается испытание на срок от двух до шести месяцев. При поступлении на службу в органы внутренних дел на должность, при замещении которой присваивается специальное звание полиции, установление испытания на срок менее трех месяцев не допускается.

На период испытания кандидат назначается стажером на соответствующую должность в органах внутренних дел без присвоения ему специального звания. Во время испытания стажер выполняет обязанности и пользуется правами в соответствии с замещаемой должностью в органах внутренних дел и условиями трудового договора. Стажеру в период испытания не разрешается ношение и хранение огнестрельного оружия. Запрещается использовать стажера в оперативных мероприятиях, когда может возникнуть угроза его жизни либо когда его самостоятельные действия в силу профессиональной неподготовленности могут привести к нарушению или ущемлению прав, свобод и законных интересов граждан. В период испытания стажер наряду с выполнением основных обязанностей и поручений по должности проходит индивидуальное обучение по месту службы под руководством непосредственного руководителя (начальника) и наставника из числа опытных сотрудников органов внутренних дел, назначаемого приказом уполномоченного руководителя. В период испытания осуществляется дальнейшее изучение деловых и личных качеств стажера.

В период испытания со стажером заключается срочный трудовой договор, на стажера распространяется действие трудового законодательства. Не позднее чем за 14 дней до окончания срока испытания непосредственный руководитель (начальник) стажера подготавливает заключение в письменной форме о выполнении стажером служебных обязанностей в период испытания. Это заключение после ознакомления с ним стажера представляется уполномоченному руководителю на утверждение ${ }^{11}$.

Заключение должно содержать одну из следующих рекомендаций: о признании стажера выдержавшим испытание; о признании стажера не выдержавшим испытание. На основании заключения руководитель органа внутренних дел не позднее чем за три дня до окончания срока испытания принимает одно из следующих решений: о заключении со стажером контракта; о расторжении со стажером трудового договора в порядке, установленном трудовым законодательством.

11 Костенников М.В., Куракин А.В., Михайлюк П.А. Правовое регулирование социальной защиты сотрудников органов внутренних дел. - Домодедово, 2012. - С. 69. 
В срок испытания не засчитываются период временной нетрудоспособности стажера и другие периоды, когда он фактически не выполнял служебные обязанности. Увеличение срока испытания на период временной нетрудоспособности стажера, а также на время его отсутствия на службе по иным уважительным причинам оформляется приказом уполномоченного руководителя.

Срок испытания засчитывается в стаж службы в органах внутренних дел (выслугу лет). Испытание не устанавливается: для граждан, назначаемых на должности высшего начальствующего состава; для граждан, поступающих в образовательные организации высшего образования МВД России для обучения по очной форме; для граждан, назначаемых на должности по результатам конкурса.

По решению руководителя федерального органа исполнительной власти в сфере внутренних дел или уполномоченного руководителя испытание может не устанавливаться для граждан, ранее проходивших службу в федеральных органах исполнительной власти на должностях, по которым предусмотрено присвоение специальных (воинских) званий.

Контракт о прохождении службы в органах внутренних дел. Контракт - это соглашение между руководителем федерального органа исполнительной власти в сфере внутренних дел или уполномоченным руководителем и гражданином, поступающим на службу в органы внутренних дел, или сотрудником органов внутренних дел о прохождении службы в органах внутренних дел и (или) замещении должности в органах внутренних дел. Контракт может заключаться на неопределенный срок или на определенный срок. Контракт, заключенный на неопределенный срок, действует до достижения сотрудником предельного возраста пребывания на службе в органах внутренних дел.

Контрактом устанавливаются права и обязанности сторон. Руководитель федерального органа исполнительной власти в сфере внутренних дел или уполномоченный руководитель обязуется гражданину, поступающему на службу в органы внутренних дел, или сотруднику органов внутренних дел обеспечить прохождение службы в органах внутренних дел в соответствии законодательством, своевременно и в полном объеме выплачивать сотруднику денежное довольствие и предоставлять ему социальные гарантии. Гражданин, поступающий на службу в органы внутренних дел, и сотрудник органов внутренних дел при заключении контракта обязуются выполнять слу- жебные обязанности в соответствии с должностным регламентом (должностной инструкцией), соблюдать ограничения и запреты, связанные со службой в органах внутренних дел, а также внутренний служебный распорядок федерального органа исполнительной власти в сфере внутренних дел, его территориального органа, подразделения.

Присвоение первых и очередных специальных званий. Первое специальное звание присваивается гражданину, впервые поступившему на службу в органы внутренних дел при назначении на должность в органах внутренних дел. Гражданину (сотруднику) присваиваются первые (очередные) специальные звания: рядового полиции, рядового внутренней службы, рядового юстиции - при назначении на должность рядового состава, а также при зачислении в образовательную организацию высшего образования или научную организацию МВД России для обучения по очной форме в должности курсанта (слушателя); младшего сержанта полиции, младшего сержанта внутренней службы, младшего сержанта юстиции - при назначении на должность младшего начальствующего состава; младшего лейтенанта полиции, младшего лейтенанта внутренней службы, младшего лейтенанта юстиции - при назначении на должность среднего начальствующего состава.

Очередные специальные звания, присваиваются сотруднику органов внутренних дел последовательно по истечении срока, установленного для прохождения службы в органах внутренних дел в предыдущем специальном звании, и при условии, что сотрудник замещает должность в органах внутренних дел, по которой предусмотрено специальное звание, равное специальному званию, присваиваемому сотруднику, или более высокое, чем специальное звание, присваиваемое сотруднику.

В случае необоснованной задержки представления сотрудника к присвоению очередного специального звания соответствующее специальное звание присваивается ему со следующего дня по истечении срока пребывания в предыдущем специальном звании.

Порядок присвоения специальных званий, соответствующих должностям высшего начальствующего состава устанавливается Президентом Российской Федерации.

Сотруднику органов внутренних дел, окончившему образовательную организацию высшего образования МВД России или назначаемому после окончания образовательной организации высшего образования федерального органа исполнитель- 
ной власти в сфере внутренних дел на должность среднего или старшего начальствующего состава, специальное звание лейтенанта полиции, лейтенанта внутренней службы или лейтенанта юстиции присваивается независимо от срока пребывания в предыдущем специальном звании ${ }^{12}$.

Сотруднику органов внутренних дел в качестве меры поощрения может быть присвоено очередное специальное звание досрочно, но не выше специального звания, предусмотренного по замещаемой должности в органах внутренних дел, а сотруднику, имеющему ученую степень или ученое звание, - на одну ступень выше специального звания, предусмотренного по замещаемой должности в органах внутренних дел (за исключением специальных званий высшего начальствующего состава).

Очередное специальное звание до полковника полиции, полковника внутренней службы, полковника юстиции включительно на одну ступень выше специального звания, предусмотренного по замещаемой должности в органах внутренних дел, может быть присвоено сотруднику органов внутренних дел по истечении установленного срока выслуги в предыдущем специальном звании.

Сотруднику органов внутренних дел при переводе на последний курс обучения по очной форме в образовательной организации высшего образования МВД России присваивается специальное звание младшего лейтенанта полиции.

Присвоение сотруднику органов внутренних дел очередного специального звания приостанавливается в случае: нахождения сотрудника в распоряжении федерального органа исполнительной власти в сфере внутренних дел, его территориального органа или подразделения - до назначения на должность в органах внутренних дел; приостановления службы в органах внутренних дел; привлечения сотрудника в качестве обвиняемого по уголовному делу, возбуждения в отношении его уголовного дела - до прекращения уголовного преследования; наложения на сотрудника дисциплинарного взыскания - до окончания действия дисциплинарного взыскания.

Перевод сотрудника органов внутренних дел. Перевод сотрудника органов внутренних дел может осуществляться на вышестоящую, равнозначную или нижестоящую должность в органах внутренних дел, в другую местность либо в связи с его зачислением в образовательную организацию

12 См.: Куракин А.В. Государственная служба в органах внутренних дел. - М., 2004. - С. 17. высшего образования федерального органа исполнительной власти в сфере внутренних дел. Перевод допускается с согласия сотрудника, выраженного в письменной форме. Должность в органах внутренних дел считается вышестоящей, если для нее предусмотрено более высокое специальное звание, чем специальное звание по прежней должности в органах внутренних дел, а при равенстве специальных званий - более высокий должностной оклад.

Следует подчеркнуть, что перевод сотрудника органов внутренних дел на вышестоящую должность рядового состава, младшего, среднего или старшего начальствующего состава осуществляется по результатам аттестации и (или) конкурса, за исключением случаев, если назначение сотрудника на вышестоящую должность в органах внутренних дел осуществляется из кадрового резерва, в котором он состоял.

Должность в органах внутренних дел считается равнозначной, если для нее предусмотрены специальное звание и должностной оклад, равные специальному званию и должностному окладу по прежней должности в органах внутренних дел. Перевод сотрудника органов внутренних дел на равнозначную должность в органах внутренних дел осуществляется: в связи с необходимостью замещения другой должности в интересах службы либо в порядке ротации; по состоянию здоровья в соответствии с заключением военно-врачебной комиссии; по личным или семейным обстоятельствам; в связи с сокращением замещаемой сотрудником должности; в связи с восстановлением сотрудника в должности, которую он замещал ранее, в случае, если эту должность замещает другой сотрудник; в связи с прекращением срочного контракта; в связи с прекращением необходимого для выполнения служебных обязанностей допуска к сведениям, составляющим государственную и иную охраняемую законом тайну; в целях устранения обстоятельств, связанных с непосредственной подчиненностью или подконтрольностью сотрудников, находящихся в отношениях близкого родства или свойства.

Должность в органах внутренних дел считается нижестоящей, если для нее предусмотрено более низкое специальное звание, чем специальное звание по прежней должности в органах внутренних дел, а при равенстве специальных званий - более низкий должностной оклад. Перевод сотрудника органов внутренних дел на нижестоящую должность в органах внутренних дел осуществляется: по состоянию здоровья в соответствии с заключением военно-врачебной комиссии; по личным или 
семейным обстоятельствам; в связи с сокращением замещаемой сотрудником должности; в порядке наложения дисциплинарного взыскания; в связи с восстановлением сотрудника в должности, которую он замещал ранее, в случае, если эту должность замещает другой сотрудник и отсутствует равнозначная должность; в связи с прекращением необходимого для выполнения служебных обязанностей допуска к сведениям, составляющим государственную и иную охраняемую законом тайну; в связи с отказом от перевода на равнозначную должность в порядке ротации; в связи с несоответствием сотрудника замещаемой должности (с учетом рекомендации аттестационной комиссии); в целях устранения обстоятельств, связанных с непосредственной подчиненностью или подконтрольностью сотрудников, находящихся в отношениях близкого родства или свойства, в соответствии с законодательством Российской Федерации.

Аттестация сотрудника органов внутренних дел. Аттестация сотрудника органов внутренних дел проводится в целях определения его соответствия замещаемой должности в органах внутренних дел. Аттестация в системе МВД России может быть очередной и внеочередной. Так, по общему правилу аттестация сотрудника органов внутренних дел проводится один раз в четыре года. В случае назначения сотрудника на другую должность в органах внутренних дел, его аттестация проводится не ранее чем через один год после назначения. Внеочередная аттестация сотрудников органов внутренних дел, претендующих на замещение должностей высшего начальствующего состава, проводится по решению Президента Российской Федерации.

Внеочередная аттестация сотрудника органов внутренних дел проводится: при решении вопроса о переводе сотрудника на вышестоящую или нижестоящую должность в органах внутренних дел; при решении вопроса о прекращении сотрудником службы в органах внутренних дел в связи с расторжением контракта; по предложению уполномоченного руководителя при рассмотрении вопросов: о переводе сотрудника на иную должность в органах внутренних дел; об увольнении сотрудника со службы в органах внутренних дел; в случае, если сотрудник не прошел проверку на профессиональную пригодность к действиям в условиях, связанных с применением физической силы, специальных средств и огнестрельного оружия. До вынесения решения о соответствии замещаемой должности в органах внутренних дел сотрудник отстраняется от выполнения обязанностей, связанных с возможным применением физической силы, специальных средств и огнестрельного оружия.

Сотрудники органов внутренних дел женского пола, находившиеся в отпуске по беременности и родам, а также сотрудники, находившиеся в отпуске по уходу за ребенком до достижения им возраста трех лет, проходят аттестацию не ранее чем через один год после выхода из отпуска ${ }^{13}$.

Для проведения аттестации сотрудников органов внутренних дел приказом руководителя федерального органа исполнительной власти в сфере внутренних дел или уполномоченного руководителя создается аттестационная комиссия, в состав которой в обязательном порядке включаются сотрудники кадрового и правового (юридического) подразделений федерального органа исполнительной власти в сфере внутренних дел, его территориального органа, подразделения. В случае необходимости, по решению уполномоченного руководителя, к работе аттестационной комиссии могут привлекаться с правом совещательного голоса члены общественных советов при федеральном органе исполнительной власти в сфере внутренних дел и его территориальных органах, общественных организаций ветеранов органов внутренних дел и внутренних войск, а также представители образовательных и научных организаций - специалисты по вопросам деятельности органов внутренних дел.

Состав аттестационной комиссии для проведения аттестации сотрудников органов внутренних дел, замещающих должности в органах внутренних дел, выполнение служебных обязанностей по которым связано с использованием сведений, составляющих государственную и иную охраняемую законом тайну, формируется с учетом положений законодательства Российской Федерации о государственной тайне.

Аттестационные комиссии должны формироваться таким образом, чтобы была исключена возможность возникновения конфликта интересов, который мог бы повлиять на рекомендации аттестационной комиссии. На время аттестации сотрудника органов внутренних дел, являющегося членом аттестационной комиссии, его членство в этой комиссии приостанавливается.

Аттестация проводится, как правило, в присутствии сотрудника органов внутренних дел. В случае неявки на аттестацию без уважительных

13 См.: Куракин А.В. Государственная служба в органах внутренних дел. - М., 2004. - С. 17. 
причин, сотрудник привлекается к дисциплинарной ответственности, а его аттестация переносится. При проведении аттестации непосредственный руководитель (начальник) сотрудника органов внутренних дел подготавливает мотивированный отзыв о выполнении сотрудником своих служебных обязанностей и предложения аттестационной комиссии. С указанным отзывом сотрудник должен быть ознакомлен не менее чем за один рабочий день до проведения аттестации.

Рекомендации аттестационной комиссии принимаются открытым голосованием. Обсуждение и голосование проводятся при наличии не менее двух третей членов аттестационной комиссии. Результаты голосования определяются большинством голосов членов аттестационной комиссии. При равенстве числа голосов сотрудник органов внутренних дел признается соответствующим замещаемой должности в органах внутренних дел. Рекомендации аттестационной комиссии оформляются протоколом, который подписывается всеми членами аттестационной комиссии, принимавшими участие в заседании.

По результатам аттестации сотрудника органов внутренних дел аттестационная комиссия принимает одну из следующих рекомендаций: сотрудник соответствует замещаемой должности в органах внутренних дел; сотрудник соответствует замещаемой должности в органах внутренних дел и рекомендуется для назначения на вышестоящую должность в органах внутренних дел; сотрудник соответствует замещаемой должности в органах внутренних дел и подлежит включению в кадровый резерв для замещения вышестоящей должности в органах внутренних дел; аттестацию сотрудника следует перенести на срок, не превышающий одного года, для устранения недостатков и упущений в служебной деятельности, указанных в отзыве его непосредственного руководителя (начальника), либо для получения сотрудником дополнительного профессионального образования с последующим переводом на иную должность в органах внутренних дел или без такового; сотрудник не соответствует замещаемой должности в органах внутренних дел и подлежит переводу на нижестоящую должность в органах внутренних дел; сотрудник не соответствует замещаемой должности в органах внутренних дел и подлежит увольнению со службы в органах внутренних дел ${ }^{14}$.

14 См.: Куракин А.В. Государственная служба в органах внутренних дел. - М., 2004. - С. 19.
По результатам аттестации сотрудника органов внутренних дел аттестационная комиссия может принять рекомендацию о его поощрении, а также внести другие предложения.

Рекомендации аттестационной комиссии заносятся в аттестационный лист сотрудника органов внутренних дел. Аттестационный лист подписывается председателем и секретарем аттестационной комиссии. Сотрудник знакомится с аттестационным листом под расписку до представления его соответствующему руководителю.

Аттестационный лист сотрудника органов внутренних дел представляется руководителю, который с учетом рекомендаций аттестационной комиссии не позднее чем через две недели после проведения аттестации принимают одно из следующих решений: о включении сотрудника в установленном порядке в кадровый резерв для замещения вышестоящей должности в органах внутренних дел; о переносе аттестации сотрудника на срок, не превышающий одного года, для устранения недостатков и упущений в служебной деятельности, указанных в отзыве его непосредственного руководителя (начальника); о переносе аттестации сотрудника на срок, не превышающий одного года, и направлении сотрудника на обучение по дополнительным профессиональным программам; о переводе сотрудника на вышестоящую или нижестоящую должность в органах внутренних дел; о расторжении с сотрудником контракта и об увольнении его со службы в органах внутренних дел; о заключении с сотрудником нового контракта. Следует отметить, что сотрудник органов внутренних дел вправе обжаловать рекомендации аттестационной комиссии в соответствии законом.

Прекращение службы в органах внутренних дел. Служба в органах внутренних дел прекращается в следующих случаях: увольнение сотрудника органов внутренних дел; гибели (смерти) сотрудника органов внутренних дел, признания сотрудника органов внутренних дел в установленном порядке безвестно отсутствующим и (или) объявление его умершим.

Сотрудник органов внутренних дел увольняется со службы в органах внутренних дел в связи с прекращением или расторжением контракта. Сотрудник органов внутренних дел, приостановивший службу в органах внутренних дел, вправе уволиться со службы в органах внутренних дел по основаниям предусмотренных законом.

Если контракт прекращается, то сотрудник органов внутренних дел может быть уволен со служ- 
бы в органах внутренних дел: а) по истечении срока действия срочного контракта; б) по достижении сотрудником предельного возраста пребывания на службе в органах внутренних дел.

Контракт может быть расторгнут, а сотрудник органов внутренних дел может быть уволен со службы в органах внутренних дел: по соглашению сторон; по инициативе сотрудника; в связи с изменением условий контракта и отказом сотрудника от продолжения службы в органах внутренних дел; по выслуге лет, дающей право на получение пенсии; в связи с несоответствием сотрудника замещаемой должности в органах внутренних дел - на основании рекомендации аттестационной комиссии; в связи с грубым нарушением служебной дисциплины; в связи с неоднократным нарушением служебной дисциплины при наличии у сотрудника дисциплинарного взыскания, наложенного в письменной форме приказом руководителя федерального органа исполнительной власти в сфере внутренних дел или уполномоченного руководителя; по состоянию здоровья - на основании заключения военно-врачебной комиссии об ограниченной годности к службе в органах внутренних дел и о невозможности выполнять служебные обязанности в соответствии с замещаемой должностью при отсутствии возможности перемещения по службе; в связи с восстановлением в должности в органах внутренних дел сотрудника, ранее замещавшего эту должность (в случае отказа сотрудника, замещающего эту должность, от перевода на другую должность в органах внутренних дел; в связи с отчислением из образовательной организации высшего образования МВД России; в связи с сокращением должности в органах внутренних дел, замещаемой сотрудником; в связи с истечением срока нахождения сотрудника в распоряжении МВД России, его территориального органа или подразделения; в связи с отказом сотрудника без уважительных причин от прохождения службы в особых условиях; в связи с отказом сотрудника от перевода на нижестоящую должность в органах внутренних дел в порядке исполнения дисциплинарного взыскания; в связи с нарушением условий контракта сотрудником; в связи с нарушением условий контракта уполномоченным руководителем; по инициативе сотрудника; в связи с переводом сотрудника на государственную службу иного вида; в связи с назначением сотрудника на государственную должность Российской Федерации; в связи с несоблюдением сотрудником ограничений и запретов, установленных федеральными закона- ми; в связи с прекращением допуска сотрудника к сведениям, составляющим государственную и иную охраняемую законом тайну, если выполнение служебных обязанностей требует допуска к таким сведениям; в связи с утратой доверия.

Контракт подлежит расторжению, а сотрудник органов внутренних дел увольнению со службы в органах внутренних дел: в связи с болезнью - на основании заключения военно-врачебной комиссии о негодности к службе в органах внутренних дел; в связи с признанием сотрудника недееспособным или ограниченно дееспособным по решению суда, вступившему в законную силу; в связи с невозможностью перевода или отказом сотрудника от перевода на иную должность в органах внутренних дел; в связи с прекращением гражданства Российской Федерации или приобретением гражданства (подданства) иностранного государства; в связи с представлением сотрудником подложных документов или заведомо ложных сведений при поступлении на службу в органы внутренних дел, а также в связи с представлением сотрудником в период прохождения службы в органах внутренних дел подложных документов или заведомо ложных сведений, подтверждающих его соответствие требованиям законодательства Российской Федерации в части, касающейся условий замещения соответствующей должности в органах внутренних дел, если это не влечет за собой уголовную ответственность; в связи с отказом сотрудника от перевода на иную должность в органах внутренних дел в целях устранения обстоятельств, связанных с непосредственной подчиненностью или подконтрольностью сотрудников, находящихся в отношениях близкого родства или свойства, в соответствии с законодательством Российской Федерации; в связи с осуждением сотрудника за преступление, а также в связи с прекращением в отношении сотрудника уголовного преследования за истечением срока давности, в связи с примирением сторон, вследствие акта об амнистии, в связи с деятельным раскаянием; в связи с призывом сотрудника на военную службу или направлением на заменяющую ее альтернативную гражданскую службу; в связи с совершением проступка, порочащего честь сотрудника органов внутренних дел; в связи с нарушением сотрудником обязательных правил при заключении контракта; в связи с истечением срока, для возобновления службы в органах внутренних дел; в связи с отказом сотрудника без уважительных причин от перевода на равнозначную должность в порядке ротации. Сотрудник 
органов внутренних дел подлежит увольнению в связи с утратой доверия.

Расторжение контракта по соглашению сторон. Контракт может быть расторгнут в любое время по соглашению сторон контракта с одновременным освобождением сотрудника органов внутренних дел от замещаемой должности и увольнением его со службы в органах внутренних дел в порядке, предусмотренном законом ${ }^{15}$.

Сотрудник органов внутренних дел имеет право расторгнуть контракт и уволиться со службы в органах внутренних дел по собственной инициативе до истечения срока действия контракта, подав в установленном порядке рапорт об этом за один месяц до даты увольнения. До истечения срока предупреждения о расторжении контракта и об увольнении со службы в органах внутренних дел сотрудник органов внутренних дел вправе в любое время в письменной форме отозвать свой рапорт. В этом случае контракт с сотрудником не расторгается и увольнение со службы не производится, если на замещаемую этим сотрудником должность в органах внутренних дел не приглашен другой сотрудник или гражданин и (или) имеются законные основания для отказа такому сотруднику или гражданину в назначении на данную должность. По истечении срока предупреждения о расторжении контракта и об увольнении со службы в органах внутренних дел сотрудник органов внутренних дел вправе прекратить выполнение служебных обязанностей при условии соблюдения им требований, предусмотренных законом.

В случае, если рапорт о расторжении контракта и об увольнении со службы в органах внутренних дел подан сотрудником органов внутренних дел в связи с невозможностью дальнейшего выполнения служебных обязанностей (зачисление в образовательную организацию, избрание (назначение) на государственную должность Российской Федерации, на должность государственной или муниципальной службы, руководитель федерального органа исполнительной власти в сфере внутренних дел или уполномоченный руководитель обязан расторгнуть контракт и уволить сотрудника со службы в срок, указанный в рапорте, с учетом времени, необходимого для передачи дел и осуществления окончательного расчета с сотрудником.

При расторжении по инициативе сотрудника органов внутренних дел срочного контракта, со-

15 См.: Куракин А.В. Государственная служба в органах внутренних дел. - М., 2004. - С. 17. трудник обязан возместить МВД России затраты на обучение, за исключением случаев расторжения контракта по одному из следующих оснований: заключение военно-врачебной комиссии о невозможности проживания члена семьи сотрудника по медицинским показаниям в местности, в которой сотрудник проходит службу в органах внутренних дел, и отсутствие возможности перевода сотрудника на службу в другую местность; необходимость постоянного ухода за отцом, матерью, супругом (супругой), сыном (дочерью) или усыновителем, нуждающимися по состоянию здоровья в соответствии с заключением органа медико-социальной экспертизы по их месту жительства в постоянном постороннем уходе (помощи, надзоре), либо достигшими пенсионного возраста, либо являющимися инвалидами I или II группы, при отсутствии возможности ухода со стороны других лиц, обязанных по закону содержать указанных граждан; необходимость ухода за ребенком, не достигшим возраста 18 лет, которого сотрудник воспитывает без матери (отца); состояние здоровья (болезнь) - на основании заключения военно-врачебной комиссии об ограниченной годности (о негодности) к службе в органах внутренних дел и о невозможности выполнять служебные обязанности в соответствии с замещаемой должностью.

В случае, если по истечении срока предупреждения о расторжении контракта и об увольнении со службы в органах внутренних дел контракт не расторгнут и сотрудник органов внутренних дел не настаивает на увольнении, действие контракта продолжается на прежних условиях.

Сотрудник органов внутренних дел не вправе расторгнуть контракт по собственной инициативе в период прохождения службы в органах внутренних дел в особых условиях.

Расторжение контракта по инициативе руководителя федерального органа исполнительной власти в сфере внутренних дел или уполномоченного руководителя и увольнение со службы в органах внутренних дел допускаются при условии заблаговременного уведомления об этом сотрудника органов внутренних дел.

Следует сказать, что контракт расторгается и сотрудник органов внутренних дел увольняется со службы в органах внутренних дел: не ранее чем через два месяца со дня уведомления о расторжении контракта или не ранее чем через две недели со дня уведомления о расторжении контракта.

С согласия сотрудника органов внутренних дел контракт может быть расторгнут до истечения сроков. 
Расторжение контракта по инициативе руководителя федерального органа исполнительной власти в сфере внутренних дел или уполномоченного руководителя в период временной нетрудоспособности сотрудника органов внутренних дел либо в период его пребывания в отпуске или в командировке не допускается.

Срочный контракт прекращается по истечении срока его действия, о чем сотрудник органов внутренних дел должен быть предупрежден в письменной форме не позднее чем за семь рабочих дней до дня истечения указанного срока.

Расторжение контракта вследствие нарушения установленных законодательством обязательных правил при его заключении, если такое нарушение исключает возможность дальнейшего замещения сотрудником органов внутренних дел должности и прохождения службы в органах внутренних дел, производится в случае: заключения с гражданином контракта в нарушение вступившего в законную силу приговора суда о лишении этого гражданина права занимать определенные должности в органах внутренних дел или заниматься определенной деятельностью; заключения с гражданином контракта, предусматривающего выполнение служебных обязанностей, противопоказанных ему по состоянию здоровья в соответствии с заключением медицинской организации, вынесенным до заключения контракта; заключения контракта с гражданином, не имеющим документа об образовании и (или) о квалификации, если выполнение предусмотренных контрактом служебных обязанностей требует специальных знаний в соответствии с законодательством Российской Федерации.

Предельный возраст пребывания на службе в органах внутренних дел составляет: для сотрудника органов внутренних дел, имеющего специальное звание генерала полиции Российской Федерации, генерал-полковника полиции, генерал-полковника внутренней службы или генералполковника юстиции, - 65 лет; для сотрудника органов внутренних дел, имеющего специальное звание генерал-лейтенанта полиции, генерал-лейтенанта внутренней службы, генерал-лейтенанта юстиции, генерал-майора полиции, генерал-майора внутренней службы или генерал-майора юстиции, - 60 лет; для сотрудника органов внутренних дел, имеющего специальное звание полковника полиции, полковника внутренней службы или полковника юстиции, - 55 лет; для сотрудника органов внутренних дел, имеющего иное специальное звание, - 50 лет.
По достижении сотрудником органов внутренних дел предельного возраста пребывания на службе в органах внутренних дел контракт прекращается и сотрудник увольняется со службы в органах внутренних дел.

С сотрудником органов внутренних дел, достигшим предельного возраста пребывания на службе в органах внутренних дел, имеющим положительную последнюю аттестацию и соответствующим требованиям к состоянию здоровья сотрудников органов внутренних дел в соответствии с заключением военно-врачебной комиссии, с его согласия и по его рапорту может ежегодно заключаться новый контракт, но не более чем в течение пяти лет после достижения предельного возраста пребывания на службе в органах внутренних дел.

Порядок заключения нового контракта с сотрудником органов внутренних дел, замещающим должность высшего начальствующего состава и достигшим предельного возраста пребывания на службе в органах внутренних дел, устанавливается Президентом Российской Федерации.

Прекращение или расторжение контракта с сотрудником органов внутренних дел, увольнение его со службы в органах внутренних дел и исключение из реестра сотрудников органов внутренних дел осуществляются руководителем федерального органа исполнительной власти в сфере внутренних дел или уполномоченным руководителем. Порядок представления сотрудников органов внутренних дел к увольнению со службы в органах внутренних дел и порядок оформления документов, связанных с прекращением или расторжением контракта, увольнением со службы и исключением из реестра сотрудников органов внутренних дел, определяются Министром внутренних дел Российской Федерации. Сотрудник органов внутренних дел, замещающий должность высшего начальствующего состава, увольняется со службы в органах внутренних дел приказом министра внутренних дел после освобождения от должности указом Президента Российской Федерации.

Сотрудник органов внутренних дел, имеющий специальное звание полковника полиции, полковника внутренней службы или полковника юстиции, увольняется со службы в органах внутренних дел приказом Министра внутренних дел. При этом дата увольнения сотрудника устанавливается приказом уполномоченного руководителя. На сотрудника органов внутренних дел, увольняемого со службы в органах внутренних дел, оформляется представление, содержащее сведения об 
основании увольнения, о стаже службы (выслуге лет) в органах внутренних дел, возрасте, состоянии здоровья сотрудника, наличии у него прав на получение социальных гарантий в зависимости от основания увольнения, а также иные сведения, перечень которых определяется МВД России.

В случае гибели (смерти) сотрудника органов внутренних дел, признания его в установленном порядке безвестно отсутствующим и (или) объявления умершим, кадровым подразделением федерального органа исполнительной власти в сфере внутренних дел оформляется заключение, содержащее сведения о членах семьи сотрудника и об иных лицах, имеющих право на получение социальных гарантий в соответствии с законодательством Российской Федерации.

Сотрудник органов внутренних дел, увольняемый со службы в органах внутренних дел, обязан сдать закрепленное за ним оружие, иное имущество и документы в соответствующее подразделение федерального органа исполнительной власти в сфере внутренних дел, его территориального органа, подразделения, а служебное удостовере- ние и жетон с личным номером в соответствующее кадровое подразделение. В последний день службы сотрудника органов внутренних дел уполномоченный руководитель или по его поручению иное должностное лицо обязаны выдать этому сотруднику трудовую книжку и осуществить с ним окончательный расчет.

Гражданин, уволенный со службы в органах внутренних дел, должен быть исключен из реестра сотрудников органов внутренних дел не позднее чем через один месяц со дня издания приказа об увольнении. Увольнение со службы в органах внутренних дел сотрудника органов внутренних дел в период его временной нетрудоспособности, пребывания в отпуске или в командировке не допускается.

Погибший (умерший), признанный в установленном порядке безвестно отсутствующим или объявленный умершим сотрудник органов внутренних дел исключается из реестра сотрудников органов внутренних дел со дня смерти (гибели) или вступления в законную силу решения суда о признании сотрудника безвестно отсутствующим или об объявлении его умершим.

\section{Библиография:}

1. Костенников М.В. Административная деятельность органов внутренних дел. Особенная часть. / М.В. Костенников, А.В. Куракин. - М.: Щит-М, 2003. - 344 с.

2. Костенников М.В. Актуальные проблемы административно-правового регулирования / М.В. Костенников, А.В. Куракин. Т. 1. - М.: Маросейка, 2010. - 496 с.

3. Костенников М.В. Административный запрет как средство противодействия коррупции в системе государственной службы / М.В. Костенников, А.В. Куракин. - М.: ЮНИТИ-ДАНА, Закон и право, $2010 .-127$ с.

4. Костенников М.В. Актуальные проблемы науки административного права / М.В. Костенников, А.В. Куракин. Т. 2. - М.: Маросейка, 2011. - 573 с.

5. Костенников М.В. Административный финансовый контроль в системе МВД России / М.В. Костенников, А.В. Куракин, В.Н. Кузнецов. - Домодедово: ВИПК МВД России, 2011. - 124 с.

6. Костенников М.В. Актуальные проблемы обеспечения законности и противодействия коррупции в системе Министерства внутренних дел Российской Федерации / М.В. Костенников, А.В. Куракин, Н.А. Овчинников. Т. 3. - М.: Маросейка, 2012. - 364 с.

7. Костенников М.В. Принципы организации и деятельности российской полиции / М.В. Костенников, А.В. Куракин // Государство и право. - 2012. - № 6. - С. 31-39.

8. Костенников М.В. Правовое регулирование социальной защиты сотрудников органов внутренних дел / М.В. Костенников, А.В. Куракин, П.А. Михайлюк. - Домодедово: ВИПК МВД России, $2012 .-60$ с.

9. Костенников М.В. Административное пресечение в деятельности полиции / М.В. Костенников, А.В. Куракин, К.А. Кареева-Попелковская. - Домодедово: ВИПК МВД России, 2013. - 161 с.

10. Куракин А.В. Государственная служба в органах внутренних дел / А.В. Куракин, М.В. Костенников. М.: Щит-М, 2004. - 192 с.

11. Куракин А.В. Государственная служба и коррупция / А.В. Куракин. - M.: Nota Bene, 2009. - 328 с.

12. Куракин А.В. Обеспечение прав и свобод человека правоохранительными органами Российской Федерации / А.В. Куракин [и др.]. - М.: ЮНИТИ-ДАНА, Закон и право, 2010. - 319 с.

13. Куракин А.В. Полиция и социальное государство / А.В. Куракин, М.В. Костенников // Российская юстиция. - 2012. - № 6. - С.55-59. 
14. Куракин А.В. Административное право: проблемы теории и перспективы развития / А.В. Куракин. M.: Nota Bene, 2013. - 385 c.

15. Куракин А.В. Предмет административно-правового регулирования в механизме противодействия коррупции в полиции / А.В. Куракин. - Домодедово: ВИПК МВД России, 2013. - 232 с.

16. Костенников М.В., Куракин А.В. Административно-правовое противодействие коррупции в системе государственной службы и в деятельности сотрудников полиции Российской Федерации и зарубежных государств. // Полицейская деятельность. - 2011. - 1. - С. 10-16.

17. М.В. Костенников, А.В. Куракин, И.Н. Кошелев Административно-правовое регулирование обеспечения собственной безопасности и противодействия коррупции в органах внутренних дел (ч. 2). // Административное и муниципальное право. - 2011. - 2. - С. 38-45.

18. Костенников М.В., Куракин А.В., Кулешов Г.Н., Несмелов П.В. Административно-правовое регулирование информационного обеспечения государственной гражданской службы в контексте противодействия коррупции (ч. 2) // Административное и муниципальное право. - 2012. - 11. - С. 14-33.

19. Трегубова Е.В., Марьян А.В., Кривоносов Д.А. Административно-правовое регулирование института правового запрета в системе государственной службы // Административное и муниципальное право. $-2010 .-8 .-$ C. 7-16.

\section{References (transliterated):}

1. Kostennikov M.V. Administrativnaya deyatel'nost' organov vnutrennikh del. Osobennaya chast'. / M.V. Kostennikov, A.V. Kurakin. - M.: Shchit-M, 2003. - 344 s.

2. Kostennikov M.V. Aktual'nye problemy administrativno-pravovogo regulirovaniya / M.V. Kostennikov, A.V. Kurakin. T. 1. - M.: Maroseika, 2010. - 496 c.

3. Kostennikov M.V. Administrativnyi zapret kak sredstvo protivodeistviya korruptsii v sisteme gosudarstvennoi sluzhby / M.V. Kostennikov, A.V. Kurakin. — M.: YuNITI-DANA, Zakon i pravo, 2010. - 127 s.

4. Kostennikov M.V. Aktual'nye problemy nauki administrativnogo prava / M.V. Kostennikov, A.V. Kurakin. T. 2. - M.: Maroseika, 2011. - 573 c.

5. Kostennikov M.V. Administrativnyi finansovyi kontrol' v sisteme MVD Rossii / M.V. Kostennikov, A.V. Kurakin, V.N. Kuznetsov. - Domodedovo: VIPK MVD Rossii, 2011. - $124 \mathrm{~s}$.

6. Kostennikov M.V. Aktual'nye problemy obespecheniya zakonnosti i protivodeistviya korruptsii $\mathrm{v}$ sisteme Ministerstva vnutrennikh del Rossiiskoi Federatsii / M.V. Kostennikov, A.V. Kurakin, N.A. Ovchinnikov. T. 3. M.: Maroseika, 2012. - 364 c.

7. Kostennikov M.V. Printsipy organizatsii i deyatel'nosti rossiiskoi politsii / M.V. Kostennikov, A.V. Kurakin // Gosudarstvo i pravo. - 2012. - № 6. - S. 31-39.

8. Kostennikov M.V. Pravovoe regulirovanie sotsial'noi zashchity sotrudnikov organov vnutrennikh del / M.V. Kostennikov, A.V. Kurakin, P.A. Mikhailyuk. — Domodedovo: VIPK MVD Rossii, 2012. - $60 \mathrm{s.}$

9. Kostennikov M.V. Administrativnoe presechenie v deyatel'nosti politsii / M.V. Kostennikov, A.V. Kurakin, K.A. Kareeva-Popelkovskaya. - Domodedovo: VIPK MVD Rossii, 2013. - $161 \mathrm{s.}$

10. Kurakin A.V. Gosudarstvennaya sluzhba v organakh vnutrennikh del / A.V. Kurakin, M.V. Kostennikov. - M.: Shchit-M, 2004. - $192 \mathrm{~s}$.

11. Kurakin A.V. Gosudarstvennaya sluzhba i korruptsiya / A.V. Kurakin. - M.: Nota Bene, 2009. — 328 s.

12. Kurakin A.V. Obespechenie prav i svobod cheloveka pravookhranitel'nymi organami Rossiiskoi Federatsii / A.V. Kurakin [i dr.]. — M.: YuNITI-DANA, Zakon i pravo, 2010. — 319 s.

13. Kurakin A.V. Politsiya i sotsial'noe gosudarstvo / A.V. Kurakin, M.V. Kostennikov // Rossiiskaya yustitsiya. 2012. — № 6. - S.55-59.

14. Kurakin A.V. Administrativnoe pravo: problemy teorii i perspektivy razvitiya / A.V. Kurakin. - M.: Nota Bene, 2013. - $385 \mathrm{~s}$.

15. Kurakin A.V. Predmet administrativno-pravovogo regulirovaniya $v$ mekhanizme protivodeistviya korruptsii $\mathrm{v}$ politsii / A.V. Kurakin. - Domodedovo: VIPK MVD Rossii, 2013. - $232 \mathrm{s.}$

16. Kostennikov M.V., Kurakin A.V.Administrativno-pravovoe protivodeistviekorruptsiiv sistemegosudarstvennoi sluzhby i v deyatel'nosti sotrudnikov politsii Rossiiskoi Federatsii i zarubezhnykh gosudarstv. // Politseiskaya deyatel'nost'. - 2011. - 1. - C. 10-16. 
Административное и муниципальное право 2 (74) • 2014

17. M.V. Kostennikov, A.V. Kurakin, I.N. Koshelev Administrativno-pravovoe regulirovanie obespecheniya sobstvennoi bezopasnosti i protivodeistviya korruptsiiv organakh vnutrennikh del (ch. 2).// Administrativnoe i munitsipal'noe pravo. - 2011. - 2. - C. 38-45.

18. Kostennikov M.V., Kurakin A.V., Kuleshov G.N., Nesmelov P.V. Administrativno-pravovoe regulirovanie informatsionnogo obespecheniya gosudarstvennoi grazhdanskoi sluzhby $\mathrm{v}$ kontekste protivodeistviya korruptsii (ch. 2) // Administrativnoe i munitsipal'noe pravo. - 2012. - 11. - C. 14-33.

19. Tregubova E.V., Mar'yan A.V., Krivonosov D.A. Administrativno-pravovoe regulirovanie instituta pravovogo zapreta v sisteme gosudarstvennoi sluzhby // Administrativnoe i munitsipal'noe pravo. - 2010. — 8. C. 7-16. 